NEW IMPRESSIONS XVI

The Great War and Modern Memory

\title{
KATE McLOUGHLIN
}

The First World War centenary commemorations and the issue of a new edition in 2013 following its author's death in 2012 make this a good time to revisit Paul Fussell's The Great War and Modern Memory. It is a book which First World War literary scholars and historians return to obsessively, with a mixture of admiration and irritation. The admiration is for the way in which Fussell pioneered thinking about the war in terms of its impact on cultural history, rather than in terms of its military or geopolitical significance; his attention to literary detail; and the emotional intensity of his argument, both moving and sobering. The irritation flows from his narrow interpretation of the conflict; his sub-Northrop Fryean mode of literary analysis; his historical inaccuracies and generalisations; and his insistence upon combat experience as the only basis on which truly to know the war. Both admiration and irritation are justified. Fussell approached the First World War through the 'classic memoirists' Siegfried Sassoon, Robert Graves and Edmund Blunden, and the 'poets of very high literary consciousness', David Jones, Isaac Rosenberg and Wilfred Owen (xv). ${ }^{1} \mathrm{He}$ supplemented what he gleaned from their writings with accounts by unknown rankand-filers he found in the archives and his personal experience of armed conflict, gained in the Second World War in the US infantry, and tried to impose order on the chaos. He identified a number of images, motifs, modes and thematic strains which he noted as recurring in these texts and which, he posited, had occurred to their authors both because they emerged from their actual war experiences and because 
they were present in the literature they were saturated in. He organised these images, motifs, modes and themes into classes - the 'Troglodyte World' of the trenches, 'Adversary Proceedings', 'Myth, Ritual, and Romance', the 'Theater of War', 'Arcadian Recourses' (pastoral), 'Soldier Boys' (homoeroticism) and a catch-all ('Oh What A Literary War') - and these became the titles of his chapters. He declared the entirety to be marked by a distinctly modern inflection: the ironic. Founded on experience and shored up by literature, it was, and is, a powerful classification. It did not represent the whole of the war, nor even the sum of experiences in the trenches, but it was enough to give a vivid and poignant impression. Methodologically and generically, it is best understood as mythography, in the dual senses of mythidentification and of myth-creation. But because Fussell insisted on the priority of experience, both in producing literature and in critiquing it, he got himself into a bind: the writers who, he thought, best expressed the First World War and its cultural impact were not the ones who had fought in it. These writers (he named Yeats, Woolf, Pound, Eliot, Lawrence, and Joyce (340)) might have absorbed the war through other means, but Fussell's insistence on firsthand experience as the only grounds of knowing left these means unexplored and a contradiction running through his argument.

Despite it, The Great War and Modern Memory remains magnetic. 'Groundbreaking,' comments a distinguished scholar of Romanticism. ${ }^{2}$ 'Seminal,' says the historian who has done most, contra Fussell, to reveal the deep historical continuities in the ways in which the war was represented and memorialised. 'The single most significant interpretation of the war and an unavoidable point of reference for all subsequent work,' concludes a leading theorist of war representation. ${ }^{4}$ Indeed, 
Fussell's book is one of the reasons the First World War is being commemorated as it is. Its perceived shortcomings have proved as influential as its many merits.

Fussell began work on the book in the early 1970s, daily news reports from the Vietnam War a constant reminder of the human cost of armed conflict. In his reading of First World War texts, he identified a recurring motif: statements that there was no adequate language to convey the realities of trench warfare. (The observation that those who tried to describe the war often disparaged the linguistic resources available was influential and other critics, most notably Vincent Sherry in The Great War and the Language of Modernism (2003), have started from the same premise.) Yet, it was clear that a suitable lexis did exist: the English language was rich in words like 'blood, terror, agony, madness, shit, cruelty, murder, sell-out, pain and hoax' as well as phrases like 'legs blown off, intestines gushing out over his hands, screaming all night, bleeding to death from the rectum' (184). (The list constitutes a fair summary of Fussell's opinion of modern warfare.) The real problem was that some people - people who had not experienced the fighting first-hand, that is - could not or would not hear them. The Great War and Modern Memory was Fussell's attempt as a critic-combatant mediator to get through to such people.

At the base of his enterprise was Frye's theory that verbal structures and thought structures mirror each other. ${ }^{5}$ Fussell put it like this: 'the individual human consciousness is a construction of humanity's own imaginative making, and [...] thus the power to think in signs and symbols is the quintessential human attribute' ${ }^{6}$ Identifying, decoding and explicating these 'signs and symbols' led back to the original 'reality', affording insight into the rhetorical management of language in the process. As a critical approach, this has eclectic affinities with New Criticism's close reading, structural anthropology and the myth analysis of Barthes and others, as well 
as Frye's archetypal criticism. ${ }^{7}$ In addition, Daniel Pick has suggested that it resembles the model of a 'generational "collective mentality" posited in early sociopsychological investigations of the First World War such as Caroline Playne's The Neuroses of Nations (1925). ${ }^{8}$ After starting professional life as a formalist, Fussell had used similar methodology in an earlier work, The Rhetorical World of Augustan Humanism (1965), which contains the following statement of Fryean thinking:

the mind being a thing that must work by means of metaphors and symbols, imagery is the live constituent in that transmission of shaped illumination from one intelligence to another which is literature. ${ }^{9}$

He was to carry the approach through to later works: Abroad: British Literary Traveling Between the Wars (1980), Class: A Guide Through the American Status System (1983), Wartime: Understanding and Behavior in the Second World War (1989) and BAD - Or, The Dumbing of America (1991). In The Great War and Modern Memory, the myth-unpacking methodology lies behind the opening statement: 'This book is about the British experience on the Western Front from 1914 to 1918 and some of the literary means by which it has been remembered, conventionalized, and mythologized' (xv).

To harvest examples of these 'literary means' of remembrance, conventionalization and mythologization, Fussell turned to those writers he thought had 'most effectively memorialized' the First World War 'with conspicuous imaginative and artistic meaning': Sassoon, Graves, Blunden, Owen, Rosenberg, David Jones (xv). As James Campbell notes, there was nothing new about this focus: John H. Johnston's English Poetry of the First World War (1964) and Bernard Bergonzi's Heroes' Twilight (1965) had already established the soldier-poets as 'synonymous with the Great War canon'. ${ }^{10}$ (Yeats famously left them out of The Oxford Book of Modern Verse on the grounds that 'passive suffering is not a theme 
for poetry', an odd comment which raises the question of what active suffering might look like. ${ }^{11}$ ) It left Fussell, like Johnston and Bergonzi before him, open to criticism for narrowness and elitism: the Great War of The Great War and Modern Memory encompasses no air or sea war, no home front, no European or Empire or female voices. ${ }^{12}$ Fussell did not need his bias pointing out. He acknowledged it in the preface to the original edition and again in the afterword to the $25^{\text {th }}$ anniversary edition of 2000 where, in a somewhat circular argument, he said that he 'chose to stay with the foot troops in the trenches' because 'that is the setting that comes to mind instantly when the war is mentioned' (364). ${ }^{13}$

To supplement his findings in the trench poets and memoirists, Fussell spent the summer of 1972 in the Imperial War Museum, consulting what he described as 'amateur memoirs' (xvi) and 'the unpretentious notations of the rank-and-file' (367). These he searched for 'displays of language that might help define the similarity of infantry experience in the two world wars and the problem of containing it in words' (368). There is a hint that Fussell had assumed what he would find in the archive before starting to look for it. If so, this would explain some less-than-convincing examples, such as the claim that batman Alfred M. Hale had in mind Christian's 'certificate' admitting to him to the Celestial City in Bunyan's Pilgrim's Progress as he contemplated his demobilization 'Yellow Paper' (153-4). As that example attests, Fussell's limited focus is distorting not only because it excludes a variety of experiences but also because it incorporates an over-estimation of the literariness even of the narrow subject group it allows itself, leading to claims such as 'Sassoon speaks for the whole British Expeditionary Force when he says, "I didn't want to die - not before I'd finished The Return of the Native, anyhow"' (177). Fussell must have 
known this could not possibly have been true: the statement represents an exemplary exaggeration in his assessment of Tommies' reading habits.

The 'distillations' (55) Fussell found by which soldiers' experiences of the Western Front were transmitted were the fixtures of trenches; the habit of binary thinking; the topoi of myth, ritual and romance; the metaphors and scenic structures of acting and theatre; pastoral; homoerotic motifs; and literary allusions. These were 'forms of [a] myth' (xv). But Fussell's mythography was more than mythidentification. His already-quoted mission statement - 'This book is about the British experience on the Western Front from 1914 to 1918 and some of the literary means by which it has been remembered, conventionalized, and mythologized' - sounds like a Lévi-Straussian view of myth, pithily summarised by Eric Leed as 'a process of selection, categorization, and recombination that make the social, technological, and economic facts of life narratable'. ${ }^{14}$ (The idea could be traced even further back, to Nietzsche's Apollonian experience and Schopenhauer's concept of representation.) In the ways they create meaning, however, Fussell's myths operate more along the lines described by Roland Barthes. 'Mythical speech,' Barthes argued, 'is made of a material which has already been worked on so as to make it suitable for communication'. ${ }^{15}$ To use Barthes's example, certain qualities of roses such as their colour, shape, scent and bloomingness are suggestive of 'passion', and have prompted and perpetuated the long cultural tradition of using roses to express that feeling. ${ }^{16}$ Having become as inseparable from their traditional usage as they are from their actual qualities, roses in art and literature now signify both real-life roses and passion. They are, in Barthes's terminology, part of a 'second-order semiological system' or 'metalanguage'. ${ }^{17}$ As it happens, roses are also one of Fussell's 'distillations', though they've had the connotation of 'passion' pruned. Instead, they are associated, again 
by 'ancient tradition', with 'battle scars', 'England', 'loyalty' and 'sacrifice' (265). Fussell points to roses in poems by Rupert Brooke, Wallace Stevens and David Jones, in memoirs by Philip Gibbs, Basil Liddell Hart and Stephen Graham, in popular song, in the bar added to the Military Cross and in military cemeteries (264-7). So identified by Fussell, listed in his chapter on 'Arcadian Recourses' along with other pastoral images, these roses take on extra signifying duty. With their connotations of wounds, patriotism, loyalty and sacrifice, they come to mean 'First World War'. It is in performing these critical acts of selection and categorization that Fussell goes beyond myth-identification to myth-creation. This is not to say that roses are not indeed prevalent in First World War writings; rather, it is to say that other images are prevalent as well, but that Fussell's selection has itself proved paradigmatic. That selection is at work is revealed not only by his down-playing the tradition of roses in love literature but also by his inability to resist expanding his range of examples. The American Wallace Stevens figures oddly in an analysis of an image of Englishness, after all; and Fussellian roses turn out to be a flexible species admitting other 'red flowers' (243) - Hardy's fuschias, Lawrence's 'red lily' and the geraniums at Buckingham Palace are also cited (244), and this is before poppies are even mentioned. Fussell chose the rose because of its long-standing literary associations, and a myth was born.

Similar issues arise with what Fussell identified as 'the versus habit' (86). The physical situation of the trenches - "We" are all here on this side; "the enemy" is over there' - led, in his view, to 'a persisting imaginative habit of modern times', namely 'gross dichotomizing' (82). What began as a battlefield 'nervous obsession with what "the other side" is up to' established 'a model of modern political, social, artistic, and psychological polarization' (83) with no hope of Hegelian synthesis. 
Gross dichotomizing is of more ancient standing than the second decade of the twentieth century, but the claim might still sound plausible enough - until Fussell begins to trace its ramifications. He discerns the versus habit in, inter alia, Eliot's dissociation of sensibility, Forster's 'only connect' (things wouldn't need connecting if they weren't already polarized), Wyndham Lewis's blasting and blessing, I. A. Richards's suggestion of the vulnerability of humanistic studies to science, the run-ins between Kingsley Amis's Jim Dixon and the university hierarchy, and Jung's model of the warring psyche (115-22). There are certainly opposing elements in all of these examples, but picking out binaries at this generalised level risks diluting the argument to homeopathic proportions. In short, gross dichotomizing feels like a hard sell, and Fussell promptly undermines it anyway by adding to the enemies the staff in the rear (90) and the civilians at home (94) ('us and them' becomes 'us and them and them and them') and then by proposing that the division of front, support and reserve made it 'natural to see everything as divisible by threes' (135). Instead of scouring texts for the contents of their figurative expressions and offering proof-by-quotation, Fussell might have explored how the images might work in, for example, connotative, aural or combinatory ways. He comes across as 'a man determined to make his point, and empty his card file, come what may, remarked Frank Kermode in an early review. ${ }^{18}$

The most famous claim in The Great War and Modern Memory is that the First World War shaped a new consciousness: a modern, specifically ironic, mindset. This argument posited the war as the end of innocence, summed up in the glorious last summer of 1914. Innocence had a language to match it, a "“high" diction' in which 'earnestly brave' was conveyed by 'gallant', 'cheerfully brave' by 'plucky', 'stolidly brave' by 'staunch', the legs and arms of young men by 'limbs' and dead bodies by 'ashes' or 'dust' (23). Innocence allowed people to use words such as 
'intercourse', 'erection' or 'ejaculation' without risking 'a smile or a leer' (24): the war undid these euphemisms while substituting others. The end of innocence was also the death of nuance - the 'versus' habit again - and Fussell reads the revival in Henry James's popularity in the Second World War as an ongoing counter-reaction. Another counter-reaction was the absurd and, for Fussell, Heller's Catch-22 and Pynchon's Gravity's Rainbow, both books mentioned approvingly several times in The Great War and Modern Memory, are the true heirs of what the First World War did to logic and language. 'Had Fussell been writing thirty years or so later, he might have considered 'The Great War and Postmodern memory as a title,' remarks Randall Stevenson; ${ }^{19}$ and Fussell did actually mention 'the "post-modern" sensibility' (348) at one point. For there is something postmodern about The Great War and Modern Memory as a work of literary criticism, not only in its epistemological eclecticism but also in its tone, which departs from the standard range of scholarly timbres in being itself ironic, sardonic, scathing. The tone is as much a product of Fussell's experiences in the Second World War as of his readings of the texts of the First: a veteran voice to match a veteran poetics.

The end-of-innocence argument has been attacked from various quarters. Historians have complained that it creates an impression of pre-war society as 'an antique, quaint place with simple values and ideas' or 'a nation lolling about in deck chairs and awaiting the fall of a wicket'. ${ }^{20}$ In $A$ War Imagined (1990), Samuel Hynes set out the end-of-innocence narrative -

a generation of innocent young men, their heads full of high abstractions like Honour, Glory, and England, went off to war to make the world safe for democracy. They were slaughtered in stupid battles planned by stupid generals. Those who survived were shocked, disillusioned and embittered by their war experiences, and saw that their real enemies were not the Germans, but the old men at home who had lied to them. They rejected the values of the society that had sent them to war, and in doing so separated their own generation from the past and from their cultural inheritance. ${ }^{21}$ 
Hynes labels it as 'myth', in fact 'the Myth of the war'. ${ }^{22}$ Fussell had said all along that he was dealing with myth ('myth' in the Fryean sense of a way of explaining, rather than in the sense of a fiction), but the end-of-innocence argument has made him a target for revisionist historians such as Gary Sheffield, keen to substitute for Hynes's 'myth' an interpretation of the war as a strategic victory. ${ }^{23}$ A different problem is that many of the examples in The Great War and Modern Memory aren't ironized anyway. Laurence Binyon's lines 'At the going down of the sun and in the morning / We will remember them' (60), for example, are offered, not as a hugely ironic claim in the light of post-war unemployment and inadequate provision for disabled veterans but as an instance of the pervasive influence of the daily dawn and dusk stand-to in the trenches; and the phenomenon of endlessness (77-81) is no more ironized. Another curiosity is that American writers are included among the ironists: Hemingway's A Farewell to Arms (257) and Wallace Stevens's 'Esthétique du Mai' (265). Was this, then, a transatlantic innocence corrupted into an international irony, and did a Second World War poet regain it only to lose it again? Earlier, Fussell had found 'a pervasive ironic pattern' in the Augustan humanists and ironies 'embedded so deeply' in Johnson's Lives of the Poets that 'they become the virtual substance'. ${ }^{24}$ It begins to look as though irony, like roses and the 'versus' habit, is everywhere: the claim that the First World War was the origin of such phenomena loses credibility.

Nonetheless, the notion of a modern, ironic mindset coming into existence between 1914 and 1918 has led to The Great War and Modern Memory being taken as the leading representative of the argument that the First World War constituted a rupture with the past. ${ }^{25}$ In this vein, Campbell writes that '[i]t is probably not an exaggeration to state that Fussell claims that modern culture is a direct product of the war' ${ }^{26}$ and Daniel Pick that '[a]gain and again Fussell stresses discontinuity with the 
world pre-1914 [...] [his] concern is always with the novelty of $1914{ }^{\prime}{ }^{27}$ The problem with assigning The Great War and Modern Memory this representative status is that, as often as he declared what was rupturing and innovative about the war and the various means of expressing it, Fussell found a predecessor. Here is one of his position statements:

Every war is ironic because every war is worse than expected. Every war constitutes an irony of situation because its means are so melodramatically disproportionate to its presumed ends. [...] But the Great War was more ironic than any before or since. (8)

The First World War was not unique, then, just a uniquely intense version of previous wars. But the unprecedented intensity was foreseeable: Fussell makes his statement after demonstrating that Thomas Hardy pre-imagined it, along with the mass deaths, hardly getting round the contradiction by labelling Hardy a 'clairvoyant' (3). Later in the book, Fussell makes the following claim:

One reason modern English poetry can be said to begin with Hardy is that he is the first to invite into poems the sound of ominous gunfire heard across the water. There is not just 'Channel Firing'; there is 'The Discovery,' written well before the war. (74)

This statement both refutes the idea that modern English poetry began with the war (it began earlier, with Hardy) and contends that it did begin with the war (it began when it incorporated the sound of cross-Channel gunfire, which was a product of the war, except that in this case the gunfire was the product of Hardy's prescient imagination). Fussell himself noted that when Oxford University Press asked Philip Larkin his opinion of the book, Larkin replied that he found it 'extremely confused' (366).

In very many similar instances, Fussell demonstrates not rupture but continuity. The sporting terminology used to characterise battle was a Victorian public school idiom (26-30). The idea of the enemy to the rear was an 'odd resumption' of the collision between Arnold's Educated and Philistines (98). The 
prevalent atmosphere of myth, ritual and romance on the Western Front was 'an approximation of the popular psychological atmosphere of the Middle Ages' (125-6). Many 'arrived at Mametz Wood and Trones Wood and High Wood primed by previous adventuring in [William] Morris's Wood Debateable and Wood Perilous' (147). As for Bunyan's Pilgrim's Progress, 'Everybody had been raised on it' (149). The pastoral tradition went back to 'English writing from the beginning' (251). The 'curious intercourse' between war and love had been experienced '[s]ince antiquity' (292). Winter remarked: "If the war created "modern memory" as Paul Fussell has claimed, it was a traditional, even archaic, kind of memory that came out of the conflict' ${ }^{28}$

But perhaps 'modern memory' meant not so much a new way of remembering as a new way of using the old ways of remembering. Fussell's vision was that experiences of the war had been configured into certain literary paradigms which enabled those experiences to be both understood and passed on. In some cases, the paradigms were newly minted by the First World War; in other cases, the war made their application newly appropriate; in still other cases, it prompted a new inflection of them. But of experience and paradigm, which was cause and which effect? Fussell's answer is, consistently, 'both were both, at the same time':

I have tried to understand something of the simultaneous and reciprocal process by which life feeds materials to literature while literature returns the favor by conferring forms upon life. (xv)

This statement points towards something with the flavour of a New Historicist textual economy. It is circular, as reciprocal exchanges are; more significantly, it doesn't specify when the process of configuration began. In the context of the First World War-as-rupture debate, this is an important point. Fussell moves towards clarification 
later in the book: 'I am saying that there seems to be one dominating form of modern understanding; that it is essentially ironic; and that it originates largely in the application of mind and memory to the events of the Great War' (38). Does this mean that the 'dominating form of modern understanding' was the product of hindsight? Did its onset occur during the war or possibly even post-war? In either case, it seems somehow to have been both posterior and retrospective and this can only mean that the events and experiences in question did not seem ironic at the time. From this point, it is a short step to positing that 'irony-assisted recall' (31) has more to do with the (coping) processes of memory than with the recollected experiences themselves. In Fussell's words: 'By applying to the past a paradigm of ironic action, a rememberer is enabled to locate, draw forth, and finally shape into significance an event or a moment which otherwise would merge without meaning into the general undifferentiated stream' (31).

The chief 'rememberer' is The Great War and Modern Memory is Fussell himself. As he worked on the book in the early '70s, he could speak to veterans with personal memories of the conflict. Furthermore, 'the whole texture of British daily life' seemed 'to commemorate the war still' (341). The war accounted for the 'odd pub-closing hours', British Summer Time, cigarette-smoking, wristwatches, allotments, paper banknotes, egg and chips, the sight of a 'middle-aged Lesbian couple in tweeds', and the 'suspicion of the press' (341-3). But Fussell was something more than a listener to tales and an observer of how the country had changed. 'All books of non-fiction are to a degree autobiographical, and this one more than most,' he wrote in the Afterword to the book's 2000 edition:

No, I did not participate in the First World War, but I did in the Second, and in the same guise as the young officers whose reactions to battle I used in this book. [...] As a wounded ex-infantry officer fascinated and sometimes 
obsessed with my experience in Europe in the Second World War, I instinctively related my circumstances to theirs. (363)

But combat experience alone would not have been enough to produce the book: what also shaped Fussell's vision was his immersion, both as amateur and as professional, in English Literature. 'Live your literature,' he heard Geoffrey Tillotson say at Harvard; ${ }^{29}$ but he needed no encouragement to read his own life as a literary work. This comes to the fore in his autobiography, Doing Battle: The Making of a Skeptic, a set of remembrances patterned in the form of an impeccably executed flashback and notable for the number of instances in which Fussell allows a quotation from another text to express his own feelings. As Campbell suggests, readers might be inclined to see Fussell not so much identifying as 'constructing' the literary tropes described in The Great War and Modern Memory since 'they represent the primary manner in which his mind makes meaning': ${ }^{30}$ such an approach would be in line with Frye's 'axiom of criticism' that the poet 'cannot talk about what he knows' ${ }^{31}$ In this view, it is Fussell's prerogative, as critic-combatant and non-poet, to isolate and explicate and so, in a sense, to construct the literary paradigms by which the war was configured. The exercise of this prerogative came naturally to Fussell, who identified in himself what he called, after studying Jacobean drama with Harry Levin, the libido dominandi. ${ }^{32}$

Fussell, like Frye, was a natural taxonomist. Feeling a 'conviction' that the First World War had been 'written by someone' (262), he settled to the tasks of dissection and classification. Looking back in 2000, he asked, 'Was I investigating the ways language could be invoked to derive some order and meaning from the messes of memory?' (363). The question is illuminating, suggesting that the images and modes described in the book are as much an expression of Fussell's libido dominandi, his desire to impose control and order, as they are of the First World War. 
In this reading, The Great War and Modern Memory becomes, rather as Frye thought the Bible and the works of Blake to be, itself a myth-generating ur-text. Leonard V. Smith makes a similar point, calling it instead a 'lieu de mémoire or "site of memory", 33 For Smith, Fussell's book, like Pierre Nora's Les Lieux de Mémoire itself, shows that 'books need not just report the past': ${ }^{34}$ they can, instead, serve as 'events that create or at least ratify how the past is remembered'. ${ }^{35}$ The Great War and Modern Memory starts to look like something more than a work of literary criticism.

If myth-manufacturing and myth-dismantling are among Fussell's major modi operandi, another is his privileging of combat experience, and his own in particular. (This was a late development: in The Rhetorical World of Augustan Humanism, he had argued that 'one need not have gone on manouevres to take full possession of contemporary military learning' and judged 'remarkable' the fact that 'Johnson's military knowledge derives mostly from literature and the sympathetic imagination'.) $)^{36}$ The point is made in the dedication of The Great War and Modern Memory, which bespeaks a special intimacy:

\author{
To the Memory of \\ Technical Sergeant Edward Keith Hudson, ASN 36548772 \\ Co. F, $410^{\text {th }}$ Infantry \\ Killed beside me in France \\ March 15, 1945
}

First-hand authorial experience also inheres in throwaway remarks such as 'the fact is if you remove cartridges from the belt the gun stops working when the empty space encounters the firing mechanism' (224) and in that characteristic veteran tone of controlled fury. But the significance of having undergone the 'most extreme experience a human being can go through' is most clearly articulated in Fussell's 
1981 essay 'Thank God for the Atom Bomb' and the scholarly exchange following it. $^{37}$ In this 'collision between experience and theory', Fussell argued that his contemporary and ongoing reaction of joy and relief to the news of the dropping of the bomb on Hiroshima was sanctioned by the experience of 'having to come to grips, face to face, with an enemy who designs your death'. ${ }^{38}$ Indeed, someone 'not socially so unfortunate as to find himself down there with the ground forces, where he might have had to compromise the purity and clarity of his moral system by the experience of weighing his own life against someone else's' had no authority to pronounce on the matter. ${ }^{39}$ The counter-arguments, from Michael Walser, were that Fussell's stance meant there were no limits at all - 'anything goes, so long as it brings the boys home' - and that the Hiroshima bombing was a pure 'act of terrorism' ${ }^{40}$ It is worth noting from the exchange Fussell's absolute equation of experience with authority (one tactic is to note his opponents' extreme youth - one, when the bomb dropped, 'was going on eight months old, in danger only of falling out of his pram' $)^{41}$ and his ability simultaneously to hold the opinions that the A-bombing was 'a vast historical tragedy' and 'precisely the right thing' ${ }^{42}$ Being able to hold both points of view at once was the outcome, Fussell said, of possessing an 'ironic and ambiguous' sensibility, this time giving irony a positive inflection as the host of 'messiness' and nuance. $^{43}$

His position in 'Thank God for the Atom Bomb', which is what The Great War and Modern Memory is also founded upon, makes Fussell an acolyte of 'combat gnosticism', the phenomenon identified by Campbell as 'the belief that combat represents a qualitatively separate order of experience that is difficult if not impossible to communicate to any who have not undergone an identical experience' ${ }^{44}$ As Campbell observes, the ideology limits the canon of texts seen as 'legitimate war 
writing', notably excluding from it anything produced by that section of humanity traditionally denied access to the combat zone: women. ${ }^{45}$ It is not difficult to spot the historiographical objections combat gnosticism invites. For Leonard Smith, the chief problem is the limitations it imposes upon interpretative authority. 'No generation, and no narrative form,' he writes, in what sounds like a personally felt grievance, 'has the exclusive claim to interpreting that war, or any war, in its myriad representations'. ${ }^{46}$ For Robin Prior and Trevor Wilson, personal experience cannot be substituted for the kind of independently verifiable evidence produced by professional historical research. Declaring The Great War and Modern Memory to be 'not [a] work of literary criticism' and asserting that 'Fussell writes as an historian', Prior and Wilson go on to criticise him for not acting like one, citing his 'plainly fanciful' statistics, his omission of the home front and of the gunners on the Western Front, his choice of witnesses ('They were much influenced [...] by John Ruskin's Modern Painters, and they spend a lot of time noticing the sky'), his 'disregard for sequence and geography' and his failure to notice any of his own limitations. ${ }^{47}$ The result is, in their view, 'an "Alice-in-Wonderland" account of the war' ${ }^{48}$ They are quite right, but it is only a problem if you expect a conventional history in the first place. Fussell was writing myth, and about myth. And myth, as he said in a letter to the New York Times after the summer he spent in the archives of the Imperial War Museum, is not history' ${ }^{49}$ His own war experiences had left him with a lifelong scepticism of official documents. ${ }^{50}$ No matter if he 'exaggerated, neglected important data, and generally behaved irresponsibly': he was avowedly writing 'like an essayist, for whom only a small part of his material was the facts and public imagery of European history'. ${ }^{51}$ His model was Martin Gilbert, whose accounts of both world wars were 'always illuminated by emotion' (365). Traditional, “'objective”" historiography was not so 
much 'impossible' as 'inhuman', 'offensively heartless and insensitive' (365). From The Great War and Modern Memory and Wartime, and from Fussell's comments upon them, a poetics emerges: a veteran poetics which is both generically and epistemologically unconventional.

But despite positing combat experience as the only grounds for knowing the war, Fussell is compelled to admit that the literary works of certain non-combatants are the best exemplars of his modern, ironized vision. In this vein, he criticizes David Jones's In Parenthesis for being 'deeply conservative' (158) - that is, not ironic enough. Jones's deployment of Arthurian legend, Welsh and English folklore, Old Testament history, Roman Catholic liturgy, Norse myth, Chaucer, Coleridge, Hopkins and Lewis Carroll serves not 'to shame the present' (as, in Fussell's view, it should) 'but really to ennoble it' (158). Fussell warns: 'The war will not be understood in traditional terms: the machine gun alone makes it so special and unexampled that it simply can't be talked about as if it were one of the conventional wars of history. Or worse, of literary history' (166). The warning comes just before the chapter titled 'Oh What A Literary War' in which Fussell enumerates the many long-standing literary paradigms via which, his argument goes, the war found expression. Later on, he states:

The roster of major innovative talents who were not involved with the war is long and impressive. It includes Yeats, Woolf, Pound, Eliot, Lawrence, and Joyce - that is, the masters of the modern movement. It was left to lesser talents - always more traditional and technically prudent - to recall in literary form a war they had actually experienced. (340)

Startlingly, this suggests that whatever literary paradigms to which the war gave rise in the writings of those who actually fought it were inadequate. What the war should have engendered, Fussell implies, via direct experience and literary immersion, was the kind of thing the non-combatant Modernists were producing with no first-hand 
knowledge of the fighting. Some speculation as to how they were producing it without combat experience would have been fascinating, but Fussell glosses over the contradiction, placing his description of The Waste Land as "“a memory of the war"” in inverted commas without further explanation (353). The expectation may be unfair: Fussell nowhere stated that his objective was to explicate Modernism, ${ }^{52}$ but it is difficult not to regret the absence of any account of where the non-combatant 'masters' might have derived their vision from as a major missed opportunity in cultural study. In Alex Goody's astute observation, Fussell's divide between 'active soldiers" and the "major innovative talents who were not involved with the war" prevented him from describing 'wider cultural effects'. ${ }^{53}$

But there are compensations. As already suggested, The Great War and Modern Memory gave literary criticism a new tone of voice. When, on 15 March 1945, Fussell was told that two of his comrades-in-arms had been killed in a shelling, he felt 'a black fury' that 'never entirely dissipated'. ${ }^{4}$ From the 1950 s on, his 'presiding emotion was annoyance, often intensifying to virtually disabling anger'. ${ }^{55}$ The list of those with whom he was angry grew long: 'habitual euphemizers, professional dissimulators, inadequately educated academic administrators, censors, artistically pretentious third-rate novelists, sexual puritans, rigid optimists and Disneyfiers of life, writers who bitch about the reviews they receive, humorless critical doctrinaires with grievances (Marxist, Feminist, what-have-you), the sly rhetoricians of the National Rifle Association, exploiters of tourists, and, of course, the President'. ${ }^{56}$ (And people got angry back: the tone of Fussell's critics is noticeably impassioned. $)^{57}$ Above all, he vented his fury on the perverters of language, the peddlers of euphemisms, clichés and lies and those guilty of a sheer lack of nuance. His weapon against them, he saw, was criticism, 'not carping but the 
perpetual obligation of evaluation' ${ }^{58}$ the critical arts of making fine distinctions, accepting complexity, and coming to careful judgement. It was more than a weapon, in fact: it was a 'duty' and even the means by which he could justify his life. ${ }^{59}$ Teaching literature, too, could administer the 'antidote' to a 'fatuous and menacing collection of American folk attitudes and behaviors'. ${ }^{60}$ 'It was in my perception of the essential evil of people acting without the constraints suggested by high culture,' Fussell wrote in his autobiography, 'that the infantry veteran and the scholar coincided.' ${ }^{61}$ The Great War and Modern Memory sprang from the same perception and the same coincidence.

As a result, it embodies the idea of scholarship as activism: 'centrifugal' criticism, in Frye's terms. ${ }^{62}$ Opposed to censorship, 'at white heat' over McCarthyism, 'bitterly angry' at men who had survived the Second World War 'in comfort and cleanliness', his country engaged in the 'terrible and apparently pointless war of attrition' that was Vietnam, Fussell wrote what he acknowledged to be 'Protest Literature'. ${ }^{63}$ (Saigon fell the same year The Great War and Modern Memory was published.) But it wasn't solely that, either. The Great War and Modern Memory is a generic composite: protest literature, mythography, creation-as-criticism, life writing, 'elegiac commentary' (365). It demonstrated, and continues to demonstrate, that responses to literature and history can be epistemologically eclectic. His Doing Battle displays this more overtly, acknowledging the contributions of family members, friends, former comrades, oral histories, other people's letters and memoirs, and regimental historians to the recovery of personal memories. ${ }^{64}$ The list points towards a mode of reaching 'truth' which is consensual and which, if it fails to reach the standards of professional historians, compensates by recognising its own contingency. It is the epistemology described by Tim O'Brien, another veteran (of Vietnam), in his 
short story ‘How To Tell A True War Story', quoted approvingly by Fussell in Doing Battle. ${ }^{65}$ 'A thing may happen and be a total lie,' writes O'Brien, 'another thing may not happen and be truer than the truth'. ${ }^{66}$ The Great War and Modern Memory is on the same epistemological spectrum, an earnest of a future in which the collaborative, revisable mode of reaching understanding enabled by the internet would flourish.

Its legacy can be counted in sales $(130,000$ by 2013), longevity (continuously in print since 1975), editions (a $25^{\text {th }}$-anniversary edition in 2000 , a posthumous edition with a new introduction by Jay Winter in 2013) and prizes: the National Book Award and the National Books Critics Circle Award for Criticism, inclusion in the Modern Library's 100 Best Non-Fiction Books of the twentieth century. ${ }^{67}$ In the words of Betty Fussell, it 'catapulted' her husband 'out of the narrow pigeon coop of English Literature and onto the postwar cultural landscapes on both sides of the Atlantic' ${ }^{68}$ More importantly, it made homoeroticism an indispensable part of debates concerning First World War experience and literature. ${ }^{69}$ The works carrying forward this aspect of The Great War and Modern Memory include Santanu Das's Touch and Intimacy in First World War Literature (2005), which acknowledges its 'oedipal relation' to Fussell's 'grand narrative'. ${ }^{70}$ In his concern to establish what British soldiers on the Western Front were actually reading, Fussell also anticipated scholarly initiatives such as the Open University's 'Reading and the First World War' research project. ${ }^{71}$ James Dawes's distinction between emancipatory and disciplinary language in The Language of War (2002) perpetuates Fussell's efforts to use the tools of rhetorical analysis to expose rhetorical tricks of distortion.

First World War studies have expanded beyond recognition since 1975, admitting the voices of women as well as men, of civilians and conscientious objectors as well as combatants, of members of the auxiliary services and children, 
and experiences from a global theatre of operations. ${ }^{72}$ Looking to the future, Daniel Pick has recommended acknowledging the importance of what might be termed an anti-genre - 'forgetting' - arguing that 'National identities [...] are founded as much on forgetting as on remembering,. ${ }^{73}$ It may well be that, after the centenary commemorations (and, some might wish, during them), the art of forgetting will come to the fore. The Great War and Modern Memory's mythography will be no less relevant: not flawless but leading the way.

\section{Harris Manchester College, Oxford}

\section{NOTES}

${ }^{1}$ Paul Fussell, The Great War and Modern Memory (New York, 2013). Subsequent references are to this edition unless otherwise stated. Page numbers are given in the text.

${ }^{2}$ Mary Favret, War at a Distance: Romanticism and the Making of Modern Wartime (Princeton, 2010), p. 43.

${ }^{3}$ Jay Winter, Sites of Memory, Sites of Mourning: The Great War in European Culture (Cambridge, 1995), p. 230.

${ }^{4}$ James Campbell, 'Interpreting the War', The Cambridge Companion to the Literature of the First World War, ed. Vincent Sherry (Cambridge, 2005), 261-79: p. 269.

${ }^{5}$ See Northrop Frye, Anatomy of Criticism (1957), p. 82.

${ }^{6}$ Paul Fussell, Doing Battle: The Making of a Skeptic (Boston, 1996), p. 251.

${ }^{7}$ See Eric J. Leed, No Man's Land: Combat and Identity in World War I (Cambridge, 1979), pp. 11921.

${ }^{8}$ Daniel Pick, War Machine: The Rationalisation of Slaughter in the Modern Age (New Haven, 1993), p. 198.

${ }^{9}$ Paul Fussell, The Rhetorical World of Augustan Humanism: Ethics and Imagery from Swift to Burke (Oxford, 1965), p. vii.

${ }^{10}$ Campbell, 'Interpreting the War', p. 267.

11 W. B. Yeats, 'Introduction', The Oxford Book of Modern Verse, 1892-1935, ed. W. B. Yeats (Oxford1936), p. xiv.

${ }^{12}$ See Santanu Das, Touch and Intimacy in First World War Literature (Cambridge, 2005), pp. 9, 9 $\mathrm{n} 23$.

${ }^{13}$ The Afterword to the 2000 edition is reprinted in the 2013 edition. Page numbers refer to the latter.

${ }^{14}$ Leed, No Man's Land, pp. 120-1.

${ }^{15}$ Roland Barthes, Mythologies, trans. Annette Lavers (2009), p. 133 (original emphasis).

${ }^{16}$ Ibid., p. 133.

${ }^{17}$ Ibid., pp. 137, 138.

${ }^{18}$ Frank Kermode, 'An Innocence Died: The Great War and Modern Memory', New York Times Magazine (31 August 1975), 2-3: p. 2.

${ }^{19}$ Randall Stevenson, Literature \& the Great War (Oxford, 2013), p. vii. See also Michèle Barrett, 'The Great War and Post-Modern Memory', New Formations 41 (Autumn 2000), 138-57.

${ }^{20}$ Pick, War Machine, p. 199. Robin Prior and Trevor Wilson, 'Paul Fussell at War', War in History 1.1 (1994), 63-80: p. 64.

${ }^{21}$ Samuel Hynes, A War Imagined: The First World War and English Culture (1990), ix.

${ }^{22}$ Ibid., p. ix (emphasis added).

${ }^{23}$ Gary Sheffield, Forgotten Victory: The First World War: Myths and Realities (2002), pp. 18-19. 
${ }^{24}$ Paul Fussell, The Rhetorical World of Augustan Humanism, p. 275; Samuel Johnson and the Life of Writing (1965), p. 275.

25 The leading representative of the opposing argument, that representation, particularly memorialisation, of the war depended upon and perpetuated fundamental historical continuities is Jay Winter's Sites of Memory, Sites of Mourning, published exactly 20 years later in 1995. Winter and Fussell had a drink when it came out, in Winter's words 'to celebrate the compatibility of our two different ways of looking at war': 'Introduction' to Fussell, The Great War and Modern Memory, p. xiii.

${ }^{26}$ Campbell, 'Interpreting the War', p. 267.

${ }^{27}$ Pick, War Machine, pp. 199, 203.

${ }^{28}$ Winter, Sites of Memory, Sites of Mourning, p. 73.

${ }^{29}$ Fussell, Doing Battle, p. 185.

${ }^{30}$ Campbell, 'Interpreting the War', p. 268.

${ }^{31}$ Frye, Anatomy of Criticism, p. 3.

${ }^{32}$ Fussell, Doing Battle, p. 248.

${ }^{33}$ Leonard V. Smith, 'Paul Fussell's The Great War and Modern Memory: Twenty-Five Years Later', History and Theory 40.2 (May 2001), 241-60: p. 242.

${ }^{34}$ Ibid., p. 245.

35 Ibid., p. 245.

${ }^{36}$ Fussell, The Rhetorical World of Augustan Humanism, pp. 143, 147.

${ }^{37}$ Published in The New Republic as 'Hiroshima: A Soldier's View' on 26 and 29 August 1981. Fussell, Doing Battle, p. 123, quoting Stephen Ambrose.

${ }^{38}$ Paul Fussell, Thank God for the Atom Bomb and Other Essays (New York, 1988), p. 24, 14, 34.

${ }^{39}$ Ibid., pp. 14, 34.

${ }^{40}$ Walser's response was published in The New Republic on 23 September 1981.Fussell, Thank God for the Atom Bomb, p. 39.

${ }^{41}$ Ibid., p. 19.

42 Ibid., p. 32.

${ }^{43}$ Ibid., p. 42.

44 James Campbell, 'Combat Gnosticism: The Ideology of First World War Criticism', New Literary History 30 (1999), 203-15: p. 203.

45 Ibid., p. 203.

${ }^{46}$ Smith, 'Paul Fussell's The Great War and Modern Memory', p. 260.

${ }^{47}$ Prior and Wilson, 'Paul Fussell at War', pp. 67, 68, 70, 69.

${ }^{48}$ Ibid., p. 71.

${ }^{49}$ Paul Fussell, 'Myth is Not History', New York Times (25 September 1972), p. 36.

${ }^{50}$ Fussell, Doing Battle, p. 160.

${ }^{51}$ Ibid., p. 267.

52 See Robert Darby, 'Oscillations on the Hotspur-Falstaff Spectrum: Paul Fussell and the Ironies of War', War in History 9 (2002), 307-31: pp. 312-5.

${ }^{53}$ Alex Goody, Modernist Articulations: A Cultural Study of Djuna Barnes, Mina Loy and Gertrude Stein (Basingstoke, 2007), p. 59.

${ }^{54}$ Fussell, Doing Battle, p. 144.

55 Ibid., p. 9.

${ }^{56}$ Ibid., p. 39.

${ }^{57}$ See, for example, the conclusion of Smith, 'Paul Fussell's The Great War and Modern Memory', p. 242.

${ }^{58}$ Fussell, Doing Battle, p. 9.

${ }^{59}$ Ibid., pp. 176, 175.

${ }^{60}$ Ibid., p. 239.

${ }^{61}$ Ibid., p. 251.

${ }^{62}$ Frye, Anatomy of Criticism, p. 72.

${ }^{63}$ Fussell, Doing Battle, p. 341; Fussell, Thank God for the Atom Bomb, p. 341; Fussell, Doing Battle, p. 213.

${ }^{64}$ Ibid., acknowledgements (unpaginated).

${ }^{65}$ Ibid., 114.

${ }^{66}$ Tim O'Brien, The Things They Carried (1991), 79.

${ }^{67} \mathrm{http}: / /$ ukcatalogue.oup.com/product/9780195133325.do\#.UgagvGT718M.

${ }^{68}$ Betty Fussell, My Kitchen Wars: A Memoir (Lincoln, 1999), p. 198. 
${ }^{69}$ See Campbell, 'Interpreting the War', p. 269. See also Smith, 'Paul Fussell's The Great War and Modern Memory', p. 241 and Jeremy Tambling, 'Repression in Mrs Dalloway's London', Essays in Criticism 39.2 (1989), 137-155: p. 148.

${ }^{70}$ Das, Touch and Intimacy, p. 9.

${ }^{71} \mathrm{http}: / /$ www.open.ac.uk/blogs/RED/?p=160.

${ }^{72}$ The scholarly milestones ensuring this diversity include Catherine Reilly's anthology Scars Upon My Heart (1981); Sandra Gilbert's thesis of the First World War as a 'festival of female misrule'; 72 Nosheen Khan's Women's Poetry of the First World War (1988); Claire M. Tylee's The Great War and Women's Consciousness (1990); Sarah Cole's Modernism, Male Friendship and the First World War (2003); and Santanu Das's Race, Empire and First World War Writing (2005). Similarly, the generic focus has widened from the trench lyric and autobiography to include, among other things, nurses' memoirs (anthologised by Margaret Higonnet in Nurses at the Front (2001)), popular literature (Jane Potter's Boys in Khaki, Girls in Print (2008)) and, most recently, the anecdote (Hope Wolf's Something Yet Unpublished (University of London PhD thesis, 2010)) and the short story (Ann-Marie Einhaus's The Short Story and the First War (2013)).

${ }^{73}$ Pick, War Machine, p. 202. 